Article

\title{
Energy Effectiveness or Economic Profitability? A Case Study of Thermal Modernization of a School Building
}

\author{
Piotr Michalak*(D), Krzysztof Szczotka (D) and Jakub Szymiczek (D) \\ Department of Power Systems and Environmental Protection Facilities, Faculty of Mechanical \\ Engineering and Robotics, AGH University of Science and Technology, Mickiewicza 30, 30-059 Kraków, Poland; \\ szczotka@agh.edu.pl (K.S.); szymiczek@agh.edu.pl (J.S.) \\ * Correspondence: pmichal@agh.edu.pl; Tel.: +48-12-617-3579
}

Citation: Michalak, P.; Szczotka, K.; Szymiczek, J. Energy Effectiveness or Economic Profitability? A Case Study of Thermal Modernization of a School Building. Energies 2021, 14, 1973.

https://doi.org/10.3390/en14071973

Academic Editor: Patrick Phelan

Received: 8 March 2021

Accepted: 31 March 2021

Published: 2 April 2021

Publisher's Note: MDPI stays neutral with regard to jurisdictional claims in published maps and institutional affiliations.

Copyright: (C) 2021 by the authors Licensee MDPI, Basel, Switzerland. This article is an open access article distributed under the terms and conditions of the Creative Commons Attribution (CC BY) license (https:/ / creativecommons.org/licenses/by/ $4.0 /)$.

\begin{abstract}
Thermal refurbishment of buildings results in certain energy, financial, and environmental effects. Such investments are financially supported in Poland after meeting the legally defined conditions of thermal protection and energy consumption. This paper presents a complex thermal modernization of a school building, performed by following Polish regulations. A detailed description of the studied object was given, and the calculation procedure was described. Then an optimal variant of an investment and an ex-post analysis were described. Simple payback time (SPBT) of modernization measures was from 15.8 years (insulation of the ceiling under the unheated attic) to 87 years for insulation of the wooden external wall, with 35.6 years for the whole project, which is shorter than the predicted lifespan of the whole building (50-70 years). Annual calculated heating demand decreased from 464.78 to 168.73 GJ, resulting in the primary energy consumption indicator (EP) of 484.44 and $129.46 \mathrm{kWh} / \mathrm{m}^{2}$, respectively. Thermal refurbishment with the replacement of an old boiler into a new wood-pellet one resulted in a significant reduction of $\mathrm{SO}_{2}$ and dust emissions from 451 to $27.5 \mathrm{~kg}$ and from 399 to $13 \mathrm{~kg}$, respectively.
\end{abstract}

Keywords: thermal modernization; energy audit; SPBT; lifespan; primary energy; usable energy; air pollutants emission

\section{Introduction}

Buildings in Poland are responsible for over 30\% of the total energy consumption. Because of the rising energy prices and environmental pollution since the end of 1980s, energy conservation emerged as one of the most important economic and policy issues. Numerous efficiency-related law regulations and support schemes have been introduced for these purposes [1-5]. In 1998, the Thermal Modernization Law was introduced [6] and the Thermal Modernization Fund was put into service [7]. To receive financial support, an energy audit was required. In the audit, an assessment of the technical condition of a building and heat source had to be performed, and the most advantageous modernization solution for an investor, including costs of its implementation, calculation of the level of anticipated savings, and the simple payback time (SPBT), had to be indicated. If required energy savings were achieved, based on audit recommendations, an optimal project was chosen for the implementation.

Because Poland is the heating-dominated country [8-10] at the beginning the most important issue was thermal modernization [11,12] mainly involving envelope insulation and new plastic PVC windows. In practice, energy auditors commonly did not take into account thermal comfort issues [13], focusing only on assuming standard requirements in auditing calculations. Moreover, residents, to lower their heating bills during the heating season, commonly minimized cooling of flats by external air infiltration installing cheap airtight windows, without trickle vents, reducing the exchange of used and fresh air and moisture removal [14]. Lack of awareness and higher costs of windows with trickle vents were indicated [15] as the main reasons for the deterioration of microclimatic conditions 
in apartments. Thus, special attention was required during the design and construction process [16] as well as monitoring during everyday use. Despite these problems, that scheme resulted in a significant reduction of heating energy $[8,17-19]$ and profited over 45,000 buildings, from which over $95 \%$ were multi-family buildings $[9,20]$, increasing their market value [21]. However, there is still not modernized significant part of the building stock in Poland [22,23]. Of these, educational buildings are of particular importance for several reasons. Primary and secondary schools in Poland are run by local governments $[24,25]$. They are interested in reducing the operation costs of schools significantly, dependent on energy consumption for heating and lighting. The second problem comes from the technical conditions of buildings. Between 1954 and 1979, there were built in Poland 17.9 thousand ( $46 \%$ ) educational buildings, for a total of 38.9 thousand estimated in 2010 [26]. Their heating demand is relatively high due to the liberal requirements of thermal protection of buildings at that time [5]. Recent national evaluation [20] indicates that $60 \%$ of educational buildings have improved energy performance. Therefore, a significant number of them still require modernization.

Because energy consumption in schools depends on many technical, operational, and organizational factors [27], the proper choice of criteria used to assess the optimal variant of a modernization project is a very complex task. Nevertheless, building codes simplify this issue, providing energy-effectiveness requirements clearly and coherently [28]. Their renovation was willingly taken in Poland, especially in cases of very energy-consuming objects, because of favorable financial support and relatively short calculated payback time of the investment [29].

Numerous examples of thermal modernizations of educational buildings in Poland have been presented recently [30-38], but economic evaluations were very simple and limited to SPBT or operation costs calculations. The energetic effect was in the foreground, but not linked to the investment cost and its projected lifetime.

On the other hand, also many authors have presented more complex methods that require complicated calculations or dedicated computer programs. Among different indicators and assessment methods there were used Net Present Value (NPV) [39], global cost [40], macroeconomic and a financial cost [41], multi-objective optimization [40], or life cycle assessment (LCA) [42-44]. These comprehensive approaches differ from those adopted in Polish regulations [45], but the general direction is the same-selection of the measure with the lowest SPBT to choose optimal variant of investment.

Analyses of environmental effects were limited mainly to $\mathrm{CO}_{2}$ emissions [46-48]. However, this is too simplistic when it comes to burning fossil fuels, especially for fine coal or other poor quality fuels, burnt in old and inefficient boilers [49-51].

In recent years, new regulations and standards regarding energy consumption in newly built and rebuilt buildings have been introduced in Poland [1,5,19,22,52]. According to formal requirements, SPBT is used to select the optimal variant of modernization. In general, thermal modernizations usually consist of several parts which differ in resulting energy savings, investment costs, and SPBT [29]. However, it is the final result of the whole project in terms of reducing energy consumption that is the most important and is the basis for its evaluation. Sometimes some long payback investments must be made to achieve the desired final result.

Three important observations emerge from the presented review. The first is a significant number of school buildings over 40 years old requiring modernization to improve their energy efficiency. The second concerns the profitability assessment of planned modernizations, taking into account the age of the buildings, their payback time, and durability. A more detailed analysis of the environmental effects should also be carried out to obtain a more complete picture of the effects of the investment.

This paper aims to fill this gap coherently presenting in detail the abovementioned issues, by providing a complete description of the completed thermal modernization investment, starting from pre-investment conditions, through energy audit and investment design to the finished project. 
In the next section, legal regulations related to energy auditing of buildings in Poland are briefly described, and the procedure to select the optimal variant of the modernization investment is given in detail. Then the case school building is presented, including its energy audit and detailed evaluation of energy, economic, and environmental effects of the completed modernization investment. Then final remarks are given.

\section{Legal Environment for Thermal Modernization of Buildings in Poland}

Thermal modernization requires expenses for its implementation. Many building owners may not complete the necessary retrofits without additional financial support. This issue is included in several legal acts, as follows:

- Act of 21 November 2008 on supporting thermo-modernization and renovation (Journal of Laws of 2008, No. 223, item 1459) [53].

- Regulation of the Minister of Infrastructure on the detailed scope and form of the energy audit and part of the renovation audit, audit card templates, as well as algorithms for assessing the profitability of a thermo-modernization project [54].

- Regulation of the Minister of Infrastructure and Development on the methodology for determining the energy performance of a building or part of a building and energy performance certificates [55].

- Ordinance of the Minister of Infrastructure on technical conditions to be met by buildings and their location [56].

- $\quad$ Regulation of the Minister of Economy on the detailed scope and method of preparing an energy efficiency audit, the template of an energy efficiency audit card, and methods of calculating energy savings [57].

Act on supporting thermo-modernization and renovation specifies the rules of financing them from the Thermo-Modernization and Renovation Fund [58-60]. It defines thermo-modernization projects as follows:

(a) The improvement resulting in a reduction in the demand for energy supplied for heating and/or domestic water heating in residential and public utility buildings,

(b) An improvement resulting in a reduction of energy losses in local heating networks and supplying them local heat sources for abovementioned objects, if they the energy requirements specified in other regulations,

(c) The realization of a network connection to a centralized heat source, in connection with the liquidation of a local heat source,

(d) Total or partial conversion of energy sources to renewable sources or the use of high-efficiency cogeneration.

An investor, carrying out one of the abovementioned tasks, may receive thermomodernization premium as a payoff loan. It is granted in the following amounts:

- $16 \%$ of the project costs,

- $21 \%$ of the project costs-in the case of when, along with the implementation of the thermal modernization project, a micro-installation of a renewable energy source with a maximum capacity of at least $1 \mathrm{~kW}$ in a residential single-family building or $6 \mathrm{~kW}$ in other buildings.

The condition for receiving the premium is an energy audit, performed following the regulation [54]. In this audit, the profitability of a thermo-modernization project is checked to verify the requirements of the act [53], and an optimal variant of an investment project is chosen. The ordinance [56] establishes maximum permissible values of primary energy consumption indicator (EP) and heat-transfer coefficient for external walls for different kinds of buildings [61]. In Reference [55], a calculation procedure to obtain primary energy $(\mathrm{EP})$, final energy $(\mathrm{EK})$, and usable energy (EU) indicators is given. That procedurewas presented, in detail, recently [62-69]. 


\section{Optimal Variant of Thermal Modernization}

\subsection{Introduction}

Supported investment is chosen from a set of measures indicated in the energy audit following their SPBT. Application of the given measure results in energy savings. These parameters are calculated by following the procedure given in Reference [54]. It is divided into different kinds of modernization measures:

- Reduction of heat transfer through walls, ceilings, and flat roofs;

- Replacement of windows or doors and the improvement of the ventilation system (natural and mechanical exhaust ventilation);

- Reduction of energy demand by a mechanical supply and exhaust ventilation system.

In all cases, a similar calculation scheme was used, but because of their application in the considered project, the two first cases are described.

\subsection{Calculation Procedure}

From the comparison of modernization measures with the same range of technical improvements, the optimal one is selected, i.e., with the shortest simple payback time. For a given improvement, SPBT is calculated from the relationship:

$$
\mathrm{SPBT}=\mathrm{C}_{\mathrm{n}} / \Delta \mathrm{O}_{\mathrm{rU}},
$$

where $\mathrm{C}_{\mathrm{n}}$-planned costs of works, PLN ( $\left.1 \mathrm{EUR} \approx 4.50 \mathrm{PLN}\right) ; \Delta \mathrm{O}_{\mathrm{rU}}$-annual energy cost savings resulting from the application of thermo-modernization improvement, per year for the n-th improvement, PLN/year.

The value of the annual energy-cost savings, $\Delta \mathrm{O}_{\mathrm{rU}}$, for the $\mathrm{n}$-th source of heat loss, for which given modernization measure is applied, is calculated from the formula:

$$
\Delta \mathrm{O}_{\mathrm{rU}}=\left(\mathrm{x}_{0} \cdot \mathrm{Q}_{0 \mathrm{u}} \cdot \mathrm{O}_{0 \mathrm{z}}-\mathrm{x}_{1} \cdot \mathrm{Q}_{1 \mathrm{u}} \cdot \mathrm{O}_{1 \mathrm{z}}\right)+12 \cdot\left(\mathrm{y}_{0} \cdot \mathrm{q}_{0 \mathrm{u}} \cdot \mathrm{O}_{0 \mathrm{u}}-\mathrm{y}_{1} \cdot \mathrm{q}_{1 \mathrm{u}} \cdot \mathrm{O}_{1 \mathrm{~m}}\right)+12 \cdot\left(\mathrm{A}_{\mathrm{b} 0}-\mathrm{A}_{\mathrm{b} 1}\right),
$$

where $x_{0}, x_{1}$-the share of the nth source in heat demand before and after the thermal modernization improvement, respectively; $\mathrm{Q}_{0 \mathrm{u}}, \mathrm{Q}_{1 \mathrm{u}}$-annual heat losses before and after the thermal modernization improvement, respectively, GJ/year,

$\mathrm{O}_{0 \mathrm{z}}, \mathrm{O}_{1 \mathrm{z}}$-Variable fee related to the distribution and transmission of a unit of energy used for heating before and after the thermal modernization improvement for the nth source, respectively, PLN; $\mathrm{y}_{0}, \mathrm{y}_{1}$-the share of the nth source in the demand for thermal power before and after the thermal modernization improvement, respectively; $q_{0 u}, q_{1 u}$ heat power demand to cover heat losses before and after the thermal modernization improvement, respectively, $\mathrm{MW} ; \mathrm{O}_{0 \mathrm{~m}}, \mathrm{O}_{1 \mathrm{~m}}$ - a fixed monthly fee related to the distribution and transmission of energy used for heating before and after the thermal modernization improvement for the nth source, respectively, PLN; $A_{b 0}, A_{b 1}$-monthly subscription fee before and after the thermal modernization improvement for the nth source, respectively, $\mathrm{PLN} /$ month.

Annual heat demand to cover heat transfer losses through external partitions is calculated from the following formula:

$$
\mathrm{Q}_{\mathrm{Ou}}, \mathrm{Q}_{1 \mathrm{u}}=8.64 \cdot 10^{-5} \cdot \mathrm{Dd} \cdot \mathrm{A} \cdot \mathrm{U}_{\mathrm{c}}, \mathrm{GJ} / \text { year, }
$$

where $\mathrm{U}_{\mathrm{c}}$-The value of the heat transfer coefficient of the building partition, $\mathrm{W} /\left(\mathrm{m}^{2} \cdot \mathrm{K}\right)$, A-Total area of a partition before and after modernization, $\mathrm{m}^{2}$, Dd-Number of degree days, calculated from the following formula:

$$
\mathrm{Dd}=\sum_{\mathrm{m}=1}^{\mathrm{Nm}}\left(\mathrm{t}_{\mathrm{w} 0}-\mathrm{t}_{\mathrm{e}}(\mathrm{m})\right) \mathrm{N}_{\mathrm{d}}(\mathrm{m}), \mathrm{K} \cdot \mathrm{d}
$$


where $t_{w 0}$-internal design temperature in heated rooms, ${ }^{\circ} \mathrm{C} ; \mathrm{t}_{\mathrm{e}}(\mathrm{m})$-monthly average outdoor air temperature, ${ }^{\circ} \mathrm{C} ; \mathrm{N}_{\mathrm{d}}(\mathrm{m})$-number of heating days in the month, $\mathrm{m} ; \mathrm{N}_{\mathrm{m}}$ 一the number of months of heating during the year.

Annual heat demand when the ventilation air is not supplied through a window or wall diffusers, windows or doors, is calculated from the following formula:

$$
\mathrm{Q}_{0}, \mathrm{Q}_{1}=8.64 \cdot 10^{-5} \cdot \mathrm{Dd} \cdot \mathrm{A}_{\mathrm{wd}} \cdot \mathrm{U}+\mathrm{Q}_{\mathrm{inf}}, \mathrm{GJ} / \text { year, }
$$

where $\mathrm{U}$-heat transfer coefficient of the window or door, $\mathrm{W} /\left(\mathrm{m}^{2} \cdot \mathrm{K}\right) ; \mathrm{A}_{\mathrm{wd}}$-total area of windows or doors, $\mathrm{m}^{2} ; \mathrm{Q}_{\text {inf }}$-annual heat demand for heating the undesirable airflow through window and door leaks, GJ/year, calculated from the following formula:

$$
\mathrm{Q}_{0 \mathrm{inf}}, \mathrm{Q}_{1 \mathrm{inf}}=1.43 \cdot 10^{-6} \cdot \mathrm{a} \cdot 1 \cdot \sum_{\mathrm{m}=1}^{\mathrm{Nm}}\left(\mathrm{t}_{\mathrm{w} 0}-\mathrm{t}_{\mathrm{e}}(\mathrm{m})\right)^{5 / 3} \cdot \mathrm{Ld}(\mathrm{m}),
$$

where a-air-flow coefficient through the gaps of windows or doors given in Reference [54], $\mathrm{m}^{3} /\left(\mathrm{m} \cdot \mathrm{h} \cdot \mathrm{daPa}^{2 / 3}\right) ; \mathrm{l}$-length of the external rebate gaps of windows or doors, $\mathrm{m}$.

Annual heat demand when the ventilation air is supplied through wall diffusers, windows, or doors is calculated from the following formula:

$$
\mathrm{Q}_{0}, \mathrm{Q}_{1}=\left(8.64 \cdot \mathrm{Sd} \cdot \mathrm{A}_{\mathrm{Ok}} \cdot \mathrm{U}+2.94 \cdot \mathrm{c}_{\mathrm{r}} \cdot \mathrm{c}_{\mathrm{w}} \cdot \mathrm{V}_{\text {nom }} \cdot \mathrm{Dd}\right) \cdot 10^{-5}, \mathrm{GJ} / \text { year }
$$

Thermal power required to cover losses by transmission is calculated from the following:

$$
\mathrm{q}_{0 \mathrm{u}}, \mathrm{q}_{1 \mathrm{u}}=10^{-6} \cdot \mathrm{A} \cdot\left(\mathrm{t}_{\mathrm{w} 0}-\mathrm{t}_{\mathrm{z} 0}\right) \cdot \mathrm{U}_{\mathrm{c}},
$$

where $t_{\mathrm{zo}}$ - design outdoor air temperature for a given climatic zone, determined under the PN-EN12831 standard [70], ${ }^{\circ} \mathrm{C}$.

Thermal power to cover heat losses through windows and doors when the ventilation air is not supplied through a window or wall diffusers, windows, or doors is calculated from the following formula:

$$
\mathrm{q}_{0}, \mathrm{q}_{1}=10^{-6} \cdot \mathrm{A}_{\mathrm{Ok}} \cdot\left(\mathrm{t}_{\mathrm{wo}}-\mathrm{t}_{\mathrm{zo}}\right) \cdot \mathrm{U}+1.65 \cdot 10^{-8} \cdot \mathrm{a} \cdot 1 \cdot\left(\mathrm{t}_{\mathrm{wo}}-\mathrm{t}_{\mathrm{zo}}\right)^{5 / 3},
$$

Thermal power demand when the ventilation air is supplied through a window or wall diffusers, windows, or doors is given by the following:

$$
\mathrm{q}_{0}, \mathrm{q}_{1}=10^{-6} \cdot \mathrm{A}_{\mathrm{Ok}} \cdot\left(\mathrm{t}_{\mathrm{wo}}-\mathrm{t}_{\mathrm{zo}}\right) \cdot \mathrm{U}+3.4 \cdot 10^{-7} \cdot \mathrm{V}_{\mathrm{obl}} \cdot\left(\mathrm{t}_{\mathrm{wo}}-\mathrm{t}_{\mathrm{zo}}\right),
$$

If a heating system is planned to be modernized, the value of the annual energy cost savings is given by the following:

$$
\Delta \mathrm{O}_{\mathrm{rU}}=\left(\mathrm{x}_{0} \cdot \mathrm{w}_{\mathrm{t} 0} \cdot \mathrm{w}_{\mathrm{d} 0} \cdot \mathrm{Q}_{0 \mathrm{H}} \cdot \mathrm{O}_{0 \mathrm{z}} / \mathrm{\eta}_{0}-\mathrm{x}_{1} \cdot \mathrm{w}_{\mathrm{t} 1} \cdot \mathrm{w}_{\mathrm{d} 1} \cdot \mathrm{Q}_{1 \mathrm{H}} \cdot \mathrm{O}_{1 \mathrm{z}} / \mathrm{\eta}_{1}\right)+12 \cdot\left(\mathrm{y}_{0} \cdot \mathrm{q}_{0 \mathrm{~m}} \cdot \mathrm{O}_{0 \mathrm{~m}}-\mathrm{y}_{1} \cdot \mathrm{q}_{1 \mathrm{~m}} \cdot \mathrm{O}_{1 \mathrm{~m}}\right)+12\left(\mathrm{~A}_{\mathrm{b} 0}-\mathrm{A}_{\mathrm{b} 1}\right),
$$

where $\mathrm{Q}_{0 \mathrm{H}}, \mathrm{Q}_{1 \mathrm{H}}$-annual heating demand of a building, $\mathrm{GJ} /$ year; $\eta_{0}, \eta_{1}$ 一total efficiency of the heating system before and after modernization, respectively; $\mathrm{w}_{\mathrm{t} 0}, \mathrm{w}_{\mathrm{t} 1}$ - factors taking into account no-heating periods during a week; $\mathrm{w}_{\mathrm{d} 0}, \mathrm{w}_{\mathrm{d} 1}$-coefficients taking into account no-heating during the day; $\mathrm{q}_{0 \mathrm{~m}}, \mathrm{q}_{1 \mathrm{~m}}$-the building's demand for thermal power before and after modernization project, respectively, MW.

The total efficiency of the heating system is calculated from the following:

$$
\eta_{0}, \eta_{1}=\eta_{\mathrm{g}} \cdot \eta_{\mathrm{d}} \cdot \eta_{\mathrm{e}} \cdot \eta_{\mathrm{s}}
$$

where $\eta_{g}$-heat generation efficiency, $\eta_{d}$ - heat distribution efficiency, $\eta_{e}$-efficiency of control, and $\eta_{\mathrm{s}}$ - heat accumulation efficiency. 


\subsection{Selection of an Optimal Variant}

Each modernization measure is considered in a minimum of two variants with the same range of improvements. SPBT, $\Delta \mathrm{S}_{\mathrm{n}}, \mathrm{Q}_{0}, \mathrm{Q}_{1}, \mathrm{q}_{0}$, and $\mathrm{q}_{1}$ are calculated. The optimal variant of a given measure is that of the shortest SPBT. Then they are arranged by increasing SPBT value. The first variant of modernization includes the first optimal measure, the second one-the first and second measure, etc. For each of them, the following are calculated:

- Total costs $\left(C_{n}\right)$, including the costs of preparing an energy audit and technical documentation, as well as costs related to the compliance with the applicable technical and construction regulations, also if this action does not bring energy savings,

- Annual savings $\Delta \mathrm{O}_{\mathrm{rU}}$ to be obtained as a result of the completed works are calculated from the following formula:

$\Delta \mathrm{O}_{\mathrm{rU}}=\mathrm{w}_{\mathrm{t} 0} \cdot \mathrm{w}_{\mathrm{d} 0} \cdot \mathrm{Q}_{0 \mathrm{H}} \cdot \mathrm{O}_{0 \mathrm{H}} / \eta_{0} \cdot \mathrm{O}_{0 \mathrm{z}}-\mathrm{w}_{\mathrm{t} 1} \cdot \mathrm{w}_{\mathrm{d} 1} \cdot \mathrm{Q}_{1 \mathrm{H}} / \eta_{1} \cdot \mathrm{O}_{1 \mathrm{z}}+12 \cdot\left(\mathrm{q}_{0 \mathrm{~m}} \cdot \mathrm{O}_{0 \mathrm{~m}}-\mathrm{q}_{1 \mathrm{~m}} \cdot \mathrm{O}_{1 \mathrm{~m}}\right]+12\left(\mathrm{~A}_{\mathrm{b} 0}-\mathrm{A}_{\mathrm{b} 1}\right)$,

- Reduction (in \%) of heat demand to the initial state before thermal modernization, Taking into account the total efficiency,

- The amount of own funds and the loan amount,

- Calculation of the amount of the thermo-modernization premium.

The first of the following variants, for which the SPBT value meets the requirements of the act, is considered optimal. Then, thermo-modernization premium can be received.

\section{Case Object}

The considered school is located in Trębowiec, in Central Poland. The nearest meteorological station for which long-term observations and typical meteorological year are available is located in Kielce [71], $58 \mathrm{~km}$ southwest of Trębowiec. Mean annual temperature for the period $1971-2000$ amounted $7.5^{\circ} \mathrm{C}$ and varied from $-2.1^{\circ} \mathrm{C}$ in February to $17.7^{\circ} \mathrm{C}$ in July. However, more significant deviations were also noticed (Figure 1b).

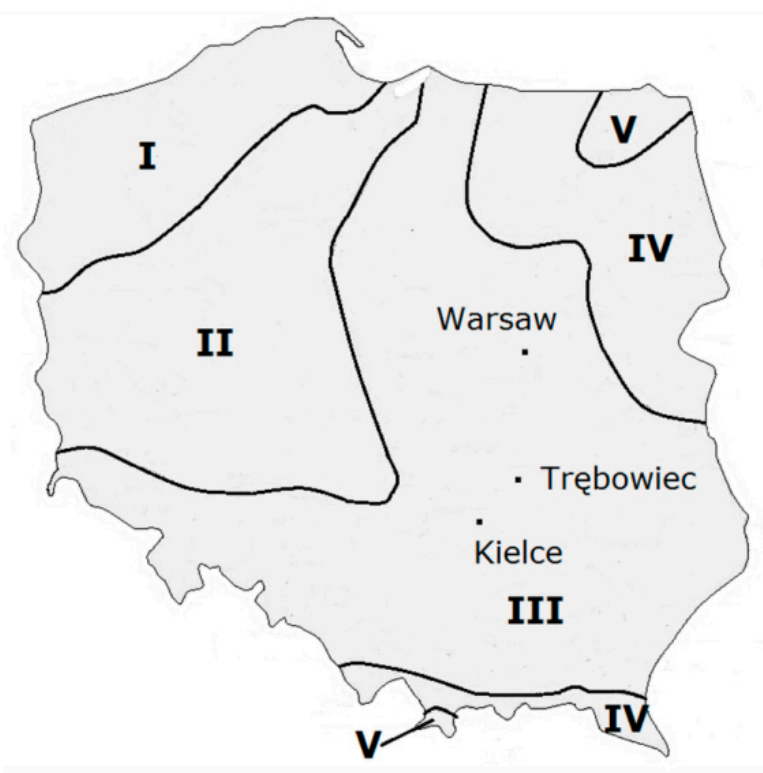

(a)

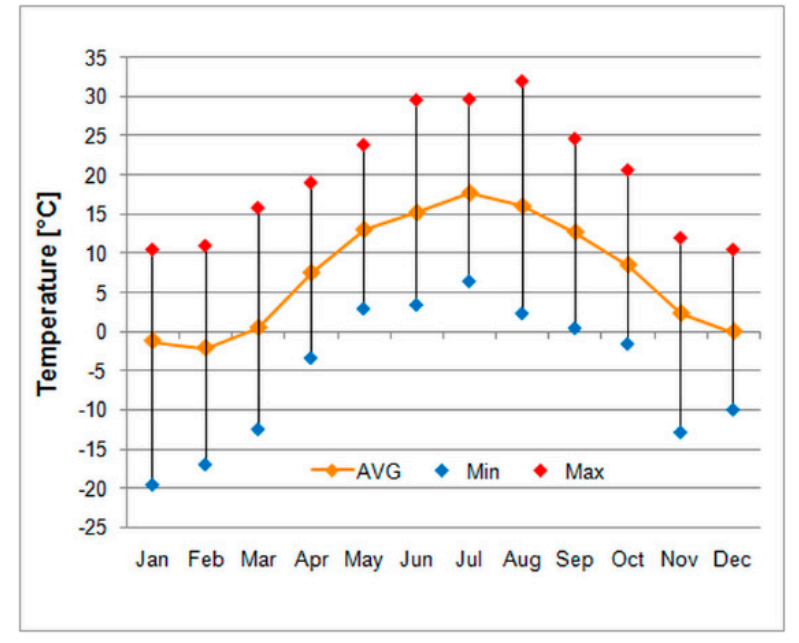

(b)

Figure 1. Considered locality. (a) Polish thermal zones according to PN-EN 12831and location of Trębowiec. (b) Monthly average, minimum, and maximum air temperature for Kielce meteorological station [71]. 
According to PN-EN12831 [70,72,73], Trębowiec is located in the III climatic zone. Following its provisions and legal requirements given in Reference [56], the design conditions for the considered location were assumed (Table 1).

Table 1. Design thermal conditions for the considered location.

\begin{tabular}{ccc}
\hline Parameter & Value & Unit \\
\hline Design outdoor temperature & -20.0 & ${ }^{\circ} \mathrm{C}$ \\
Indoor air temperature-usable premises & 20.0 & ${ }^{\circ} \mathrm{C}$ \\
Indoor air temperature-staircase & 16.0 & ${ }^{\circ} \mathrm{C}$ \\
Indoor air temperature-cellar & 12.0 & ${ }^{\circ} \mathrm{C}$ \\
Heating degree days-external partitions $\left(20.0^{\circ} \mathrm{C}\right)$ & 4538.3 & $\mathrm{~K} \cdot \mathrm{d}$ \\
Heating degree days-external partitions $\left(16.0^{\circ} \mathrm{C}\right)$ & 3078.3 & $\mathrm{~K} \cdot \mathrm{d}$ \\
\hline
\end{tabular}

The school is a three-story building built in 1970 in traditional technology from bricks (Figure 2). It has a total heated volume and area of $2807 \mathrm{~m}^{3}$ and $981 \mathrm{~m}^{2}$, respectively, including a residential part (two flats) of $142.70 \mathrm{~m}^{2}$. The number of pupils was 60 .



Figure 2. External view of the school before modernization.

Due to high exploitation costs of the building, local authorities commissioned an energy audit in terms of the possibility of lowering building operating costs by reducing building heat losses and improving energy efficiency and using investment support mechanisms to meet legal requirements for buildings in force from the 2021 year, called WT2021 (Technical Conditions 2021) [56,74].

Taking into account conclusions presented in Section 1,it can be stated that the building is representative for a significant part of Polish schools: It was built before 1980 and is located in the third climatic zone, the largest in area of all five zones. Moreover, typical building materials were used, and a typical central heating system was applied. 


\section{Energy Audit}

\subsection{Introduction}

An on-site inspection showed that the brick and wooden external walls, the wooden ceiling under the unheated attic, and concrete floors on the ground and in the basement were not insulated. The wooden roof was partially insulated with $14 \mathrm{~cm}$ thick mineral wool. Old external doors and PVC windows didnot meet the standards (Table 2).

Table 2. Thermal parameters of external partitions before modernization against technical requirements for buildings from the 2017 year (WT2017) and 2021 year (WT2021).

\begin{tabular}{|c|c|c|c|}
\hline Partition & $\mathrm{U}_{\text {actual }}\left(\mathrm{W} / \mathrm{m}^{2} \mathrm{~K}\right)$ & $\mathrm{U}_{2017}\left(\mathrm{~W} / \mathrm{m}^{2} \mathrm{~K}\right)$ & $\mathrm{U}_{2021}\left(\mathrm{~W} / \mathrm{m}^{2} \mathrm{~K}\right)$ \\
\hline \multicolumn{4}{|c|}{ External Walls, $t_{i} \geq 16{ }^{\circ} \mathrm{C}$} \\
\hline External wall (bricks) & 1682 & 0.230 & 0.200 \\
\hline Wooden external wall & 0.423 & 0.230 & 0.200 \\
\hline \multicolumn{4}{|c|}{ External Walls, $\mathrm{t}_{\mathrm{i}}<16^{\circ} \mathrm{C}$} \\
\hline Wall by the ground & 0.782 & 0.300 & 0.300 \\
\hline \multicolumn{4}{|c|}{ Roof, $\mathrm{t}_{\mathrm{i}}<16^{\circ} \mathrm{C}$} \\
\hline Not insulated roof & 2493 & 0.300 & 0.300 \\
\hline Insulated roof & 0.438 & 0.300 & 0.300 \\
\hline \multicolumn{4}{|c|}{ Ceiling, $t_{i} \geq 16{ }^{\circ} \mathrm{C}$} \\
\hline Ceiling under an unheated attic & 1300 & 0.180 & 0.150 \\
\hline \multicolumn{4}{|c|}{ Floors on the Ground, $\mathrm{t}_{\mathrm{i}} \geq 16^{\circ} \mathrm{C}$} \\
\hline Floor on the ground & 0.435 & 0.300 & 0.300 \\
\hline Floor in the cellar & 0.440 & 0.300 & 0.300 \\
\hline \multicolumn{4}{|c|}{ External Doors } \\
\hline External doors & $1.80 / 3.00$ & 1.50 & 1.30 \\
\hline \multicolumn{4}{|c|}{ External Windows } \\
\hline External windows & $1.80 / 3.00$ & 1.10 & 0.90 \\
\hline
\end{tabular}

Performed energy audit revealed several important disadvantages and sources of losses and indicated ways of improvement:

- Reduction of heat losses through external partitions_-recommended additional insulation;

- Reduction of heat losses through leaky windows and by ventilation air-application of controlled ventilation with the use of diffusers;

- Increasing the efficiency of central heating installations/replacement of the coal-fired boiler room with a new automatic, efficient biomass boiler. Modernization of piping and radiators;

- Tap water and lightingdonot require modernization;

- New on-grid photovoltaic installation to partially cover electricity consumption.

Additional insulation of the roof was not considered, because the attic was neither heated nor used. Therefore, the insulation of the ceiling under the attic was sufficient. It was also not planned insulation of the floor on the ground, due to the high costs associated with a wide range of construction works and practical limitations resulting from the necessity to exclude these rooms from use.

\subsection{Modernization of External Partitions}

An evaluation of the profitability of improvements regarding the reduction of heat losses by transmission through external partitions and by ventilation air was performed in several steps, for external partitions, windows, and doors. Then a list of optimal variants of modernization measures in order according to increasing SPBT was composed. 
For external walls, additional insulation with expanded polystyrene (EPS) with a thermal of $\lambda=0.032 \mathrm{~W} / \mathrm{m} \cdot \mathrm{K}$. The calculation of thermal resistance takes into account the cement-cement plaster lime layer on the insulation with a thermal conductivity coefficient of $\lambda=0.82 \mathrm{~W} / \mathrm{m} \cdot \mathrm{K}$ and thickness of $\mathrm{d}=0.01 \mathrm{~m}$. Three options were considered, differing in the thickness of the thermal insulation layer:

- Variant 1: with a thickness of the insulation layer at which the thermal resistance requirement WT2021 will not be met,

- Variant 2: with insulation $2 \mathrm{~cm}$ thicker than in the Variant 1 meeting WT 2021,

- Variant 3: with insulation $2 \mathrm{~cm}$ thicker than in the Variant 2.

There was also recommended replacement of existing windows into windows with better U-values and with diffusers was considered in two variants:

- Variant 1: windows with the coefficient $\mathrm{U}=1.1 \mathrm{~W} / \mathrm{m}^{2} \mathrm{~K}$ (WT2017).

- Variant 2: windows with the coefficient $\mathrm{U}=0.9 \mathrm{~W} / \mathrm{m}^{2} \mathrm{~K}$ (WT2021).

Existing external doors were also indicated to be replaced into that with better Uvalues was considered in two variants:

- $\quad$ Variant 1: doors with the coefficient $\mathrm{U}=1.5 \mathrm{~W} / \mathrm{m}^{2} \mathrm{~K}$ (WT2017).

- Variant 2: doors with the coefficient $\mathrm{U}=1.3 \mathrm{~W} / \mathrm{m}^{2} \mathrm{~K}(\mathrm{WT2} 21)$.

\subsection{Modernization of the Heating System}

The important part of the planned modernization was the replacement of an old coal-fired boiler and inefficient heating distribution system into new biomass (wood pellet) boiler with a capacity of $70 \mathrm{~kW}$ with a vertical exchanger and an automatically cleaned tilting cast iron grate, with an automatic start and stop circuit, with a pneumatic fuel transport system to the boiler and a $1000 \mathrm{~L}$ buffer tank. Moreover, replacement of existing central heating installation into cast iron radiators for plate (35 pcs.) with thermostatic valves was planned. The parameters of both systems are presented in Table 3.

Table 3. The efficiency of the heating system: before and after modernization.

\begin{tabular}{cccc}
\hline Parameter & Symbol & Current State & Planned \\
\hline Generation efficiency & $\eta_{\mathrm{H}, \mathrm{g}}$ & 0.82 & 0.85 \\
Distribution efficiency & $\eta_{\mathrm{H}, \mathrm{d}}$ & 0.80 & 0.96 \\
Efficiency of control and use & $\eta_{\mathrm{H}, \mathrm{e}}$ & 0.77 & 0.93 \\
Accumulation efficiency & $\eta_{\mathrm{H}, \mathrm{s}}$ & 1.00 & 0.95 \\
The total efficiency of the system & $\eta_{\mathrm{Htot}}$ & 0.51 & 0.72 \\
Heating breaks during the week & $\mathrm{w}_{\mathrm{t}}$ & 0.85 & 0.85 \\
Heating breaks during the day & $\mathrm{w}_{\mathrm{d}}$ & 0.95 & 0.95 \\
\hline
\end{tabular}

\subsection{Energy Consumption for Heating}

To evaluate energy effects heating consumption in the current state was calculated in the Audytor OZC [74-76] program (Version 6.8 Pro, Sankom, Warsaw, Poland), by applying the monthly method of PN-EN ISO13790 [77]. The model of the building was created (Figure 3), and all partitions were defined according to the documentation and verification during the on-site examination.

Annual heating demand was 464.78 GJ and varied, excluding the non-heating period from June to August, from 3.87 GJ in May to 88.79 GJ in February (Figure 4). The most significant annual losses were that through external walls and amounted 412.29 GJ. Assuming total efficiency of the heating system and heating breaks given in Table 3, energy saving, calculated at the input to the boiler (fuel) resulting only from heating-system replacement, was evaluated at 222.43 GJ. The heating demand for domestic hot water (DHW) preparation remained the same: $\mathrm{Q}_{\mathrm{DHW}}=29.7 \mathrm{GJ}$. 


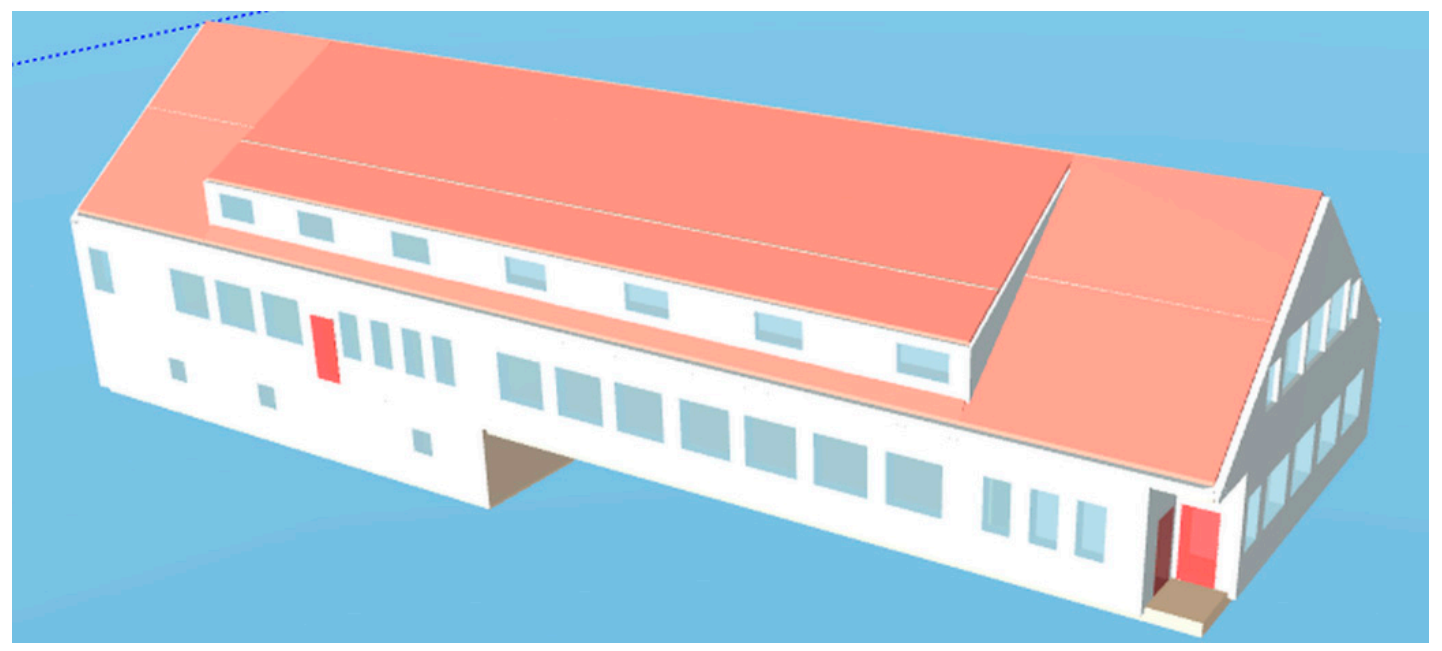

Figure 3. View of the school in the Audytor OZC program.

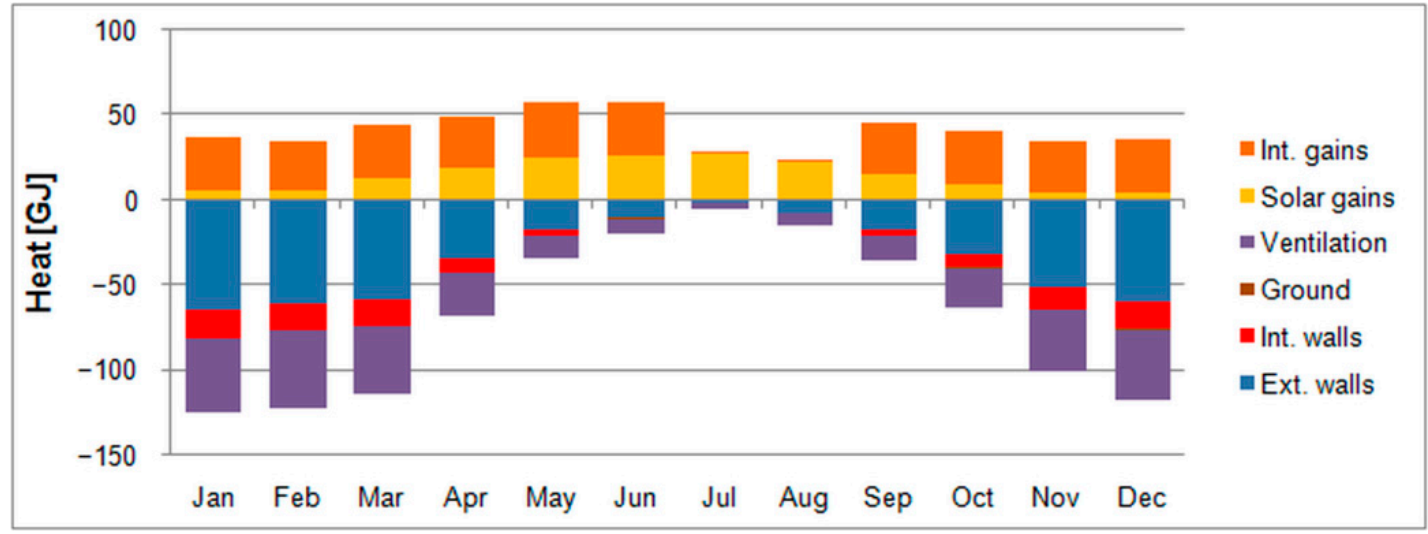

Figure 4. Heat gains and losses in the building before modernization.

\section{Economic and Energy Analysis of Modernization}

\subsection{Introductory Analysis}

Following outcomes presented in Section 4, algorithm from Section 3, and assumptions given in Table 1, calculations were performed for selected partitions according to the audit's recommendations. Unit prices of $1 \mathrm{~m}^{2}$ insulation were assumed according to the Sekocenbud nationwide (Polish) price list. Prices of materials were assumed according to the offers of local contractors. VAT of $23 \%$ on construction materials was included.

Performed calculations showed that the largest reduction of energy consumption for heating could be obtained for the new heating system (222 GJ). The external brick walls and ceiling modernization and window replacement (Figure $5 \mathrm{a}$ ) could also bring significant effects. They amounted, depending on the variant, from 160 to 165 GJ, from 147 to 151 GJ, and from 113 to $125 \mathrm{GJ}$, respectively.

In addition to the heating system (329,000 PLN), a very expensive part of the planned investment (Figure 5b) was windows replacement: from 138,596 to 149,833 PLN. External brick walls and ceiling insulation were valued from 78,696 to 83,774 PLN and from 70,798 to 74,843 PLN, respectively. The unit cost of works, computed per $1 \mathrm{~m}^{2}$ of the renewed area, was from 190.65 to $202.95 \mathrm{PLN} / \mathrm{m}^{2}$ and from 212.25 to $227.55 \mathrm{PLN} / \mathrm{m}^{2}$ for external walls and ceiling, respectively. For windows and doors, it was several times greater and was from 910.20 to $984.00 \mathrm{PLN} / \mathrm{m}^{2}$ and from 1156.20 to $1230.00 \mathrm{PLN} / \mathrm{m}^{2}$, respectively. 


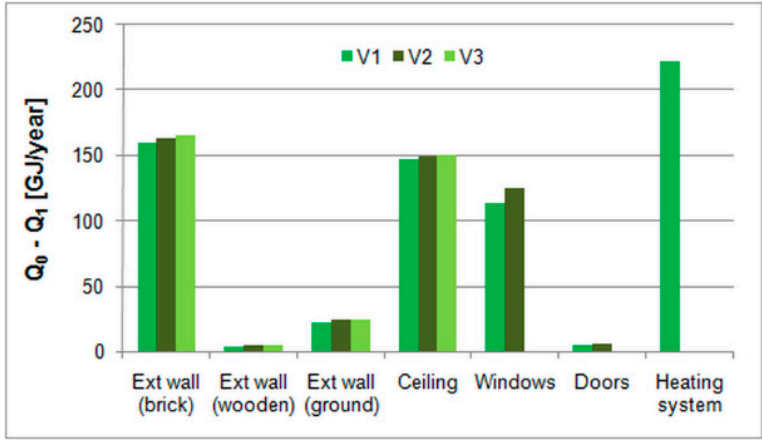

(a)

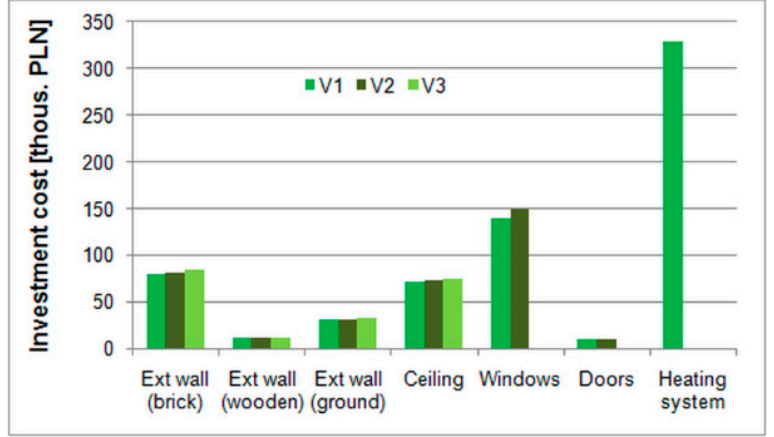

(b)

Figure 5. Modernisation variants. (a) Energy savings of the individual measures. (b) Investment costs of individual measures.

Modernization of external brick walls, ceiling and windows were the costliest parts of the planned investment. It was so because of the large areas in these cases. However important, the total cost is not the only factor deciding about the implementation of the investment. The effectiveness of the considered project can be shown in several ways. Two of them are presented in Figure 6.

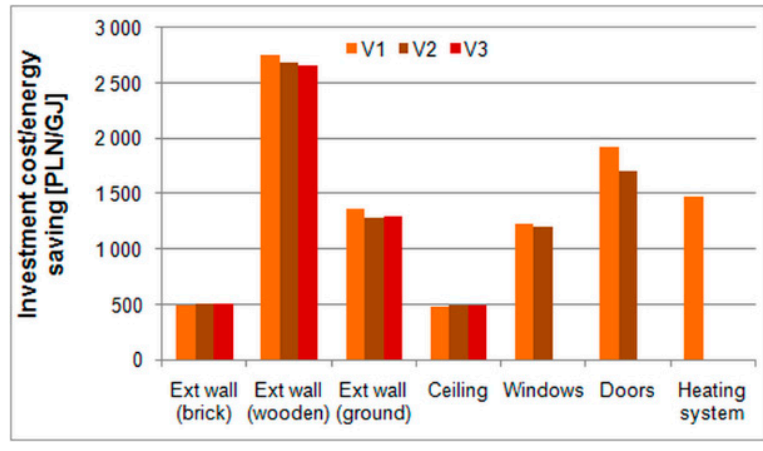

(a)

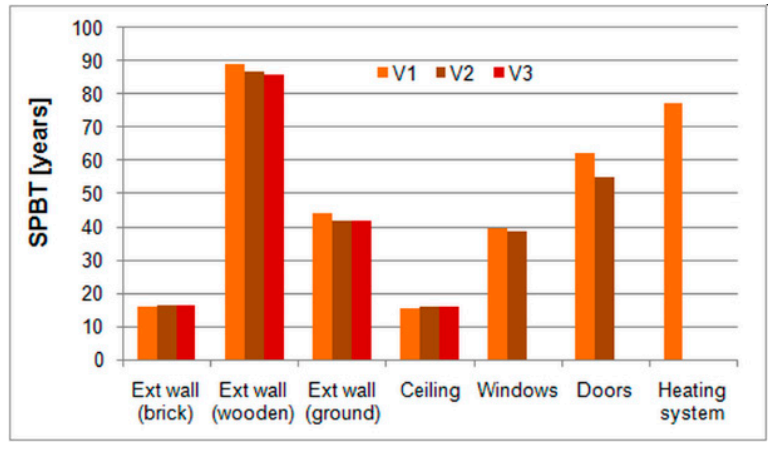

(b)

Figure 6. Modernisation variants. (a) Investment cost per energy saving. (b) Simple payback time (SPBT).

The most effective modernization measure was the insulation of the ceiling which resulted in the cost of 480.00 to 496.31 PLN per 1 GJ of saved heating energy. Moreover, the external brick wall presented a similar level of effectiveness: from 493.52 to 507.47 PLN/GJ. The least effective was the improvement of the wooden wall, resulting in savings of $1 \mathrm{GJ}$ for the price from 2759.07 to 2658.97 PLN. Despite the largest reduction of energy consumption resulting from heating system replacement, its high cost resulted in the moderate cost of saved energy: 1479.12 PLN/GJ. This tendency was also expressed directly in the SPBT values (Figure $6 b$ ).

For comparison, results from several studies related to thermal refurbishment were given here. Ferrari and Romeo [78] presented an evaluation of the historical Italian school building modernization to meet the nearly Zero Energy Building (nZEB) standard. Calculated unit cost of roof insulation $=39.1 \mathrm{EUR} / \mathrm{m}^{2}$, basement insulation $=44.7 \mathrm{EUR} / \mathrm{m}^{2}$, external wall insulation $=55.9 \mathrm{EUR} / \mathrm{m}^{2}$, and new windows $=326.9 \mathrm{EUR} / \mathrm{m}^{2}$. The retrofit of a school (1641 $\mathrm{m}^{2}$ of occupied area) in Spain to the nZEB standard [79] resulted in unit investment costs from $75.6 \mathrm{EUR} / \mathrm{m}^{2}$ for insulation under cantilevered floors, $97.0 \mathrm{EUR} / \mathrm{m}^{2}$ for ceiling insulation $(15 \mathrm{~cm})$ to $115.1 \mathrm{EUR} / \mathrm{m}^{2}$ for external wall insulation $(15 \mathrm{~cm}$ XPS). More expensive was a replacement of old windows into new with double glazing low emissivity: $578.7 \mathrm{EUR} / \mathrm{m}^{2}$, and window area enlargement in south and east façade cost 1232.5 EUR $/ \mathrm{m}^{2}$. The cost of the photovoltaic system $\left(305 \mathrm{~m}^{2}\right)$ amounted 108,050.01 EUR. 
The total investment cost of 1,369,276.40 EUR resulted in annual heating and electricity savings of 830,573.00 EUR and 567,657.00 EUR, respectively, and SPBT = 41 years.

In Reference [80], detailed calculation of the total cost for retrofit of the Portuguese residential building, including replacement of the existing windows with double glass, insulation of external walls $(7 \mathrm{~cm}$ brick wall $+10 \mathrm{~cm}$ EPS), insulation of the concrete slab $(6 \mathrm{~cm}$ EPS), and application of vinyl floor coating over EPS, $20 \mathrm{~mm}$ thick, resulted in the value of $62.44 \mathrm{EUR} / \mathrm{m}^{2}$. Unit prices for $5 \mathrm{~cm}$ thick standard EPS insulation $(\lambda=0.038 \mathrm{~W} / \mathrm{m} \cdot \mathrm{K})$ and EPS with $\lambda=0.03 \mathrm{~W} / \mathrm{m} \cdot \mathrm{K}$ of $2.3 \mathrm{EUR} / \mathrm{m}^{2}$ and $2.7 \mathrm{EUR} / \mathrm{m}^{2}$, respectively, were given in Reference [81].

\subsection{Optimal Variant}

According to previous assumptions, between auditors and investor (local authority) in all cases, Variant 2 was chosen, i.e., fulfilling legal requirements for the year 2021 (WT2021). As a result, the target physical condition of the modernized partitions was determined. Thanks to this, it was possible to calculate the heat demand for heating the building before and after the planned investment and to fully evaluate it. Then all measures were arranged according to the increasing SPBT value, as shown in Table 4 . Annual energy cost savings were estimated at 20,525.56 PLN and a reduction of the final energy demand at $64.3 \%$. This variant was accepted for further implementation.

Table 4. Modernization measures arranged according to rising SPBT.

\begin{tabular}{ccc}
\hline Type and Range of Modernization Improvement & Cost (PLN) & SPBT (Years) \\
\hline Insulation of the ceiling under the unheated attic & $72,820.67$ & 15.8 \\
Insulation of the external wall (bricks) & $81,235.10$ & 16.1 \\
Installation of a photovoltaic installation & $77,407.59$ & 22.8 \\
Replacement of external windows & $149,833.68$ & 38.8 \\
Insulation of the wall by the ground & $31,224.29$ & 41.6 \\
Replacement of the external doors & $10,221.30$ & 55.1 \\
Modernization of the central heating installation & $297,537.01$ & 70.0 \\
Insulation of the wooden external wall & $11,164.46$ & 87.0 \\
\hline Total & $731,444.10$ & 35.6 \\
\hline
\end{tabular}

\section{Ex-Post Analysis}

\subsection{Energy Effects}

The modernization works were completed in August 2018, and the school was put into operation (Figure 7). Two biomass-fired boilers, $38 \mathrm{~kW}$ each, were also installed (Figure 8). Additionally, a $5.4 \mathrm{~kW}$ photovoltaic installation was installed in the building.

According to the ex-post audit, heating consumption decreased to $168.73 \mathrm{GJ}$ and varied from 0.28 GJ in May to 38.27 GJ in February. Ventilation heat loss was still the most significant part of the thermal balance (Figure 9), but the reduction of heat losses through external partitions is noticeable.

The effectiveness of the analyzed project can be also described by several indicators defined in Polish regulations (Table 5). Total heat demand for space heating and domestic hot water decreased by $70.0 \%$. Electricity consumption from the electrical grid $\left(\mathrm{E}_{\mathrm{E}}\right)$, thanks to the installation of photovoltaic (PV) panels, was reduced by $18.8 \%$. Usable energy (EU) for heating ventilation and DHW, decreased by $57.7 \%$, from 173.80 to $73.60 \mathrm{kWh} / \mathrm{m}^{2}$.

Maximum allowable primary energy consumption (EP) for schools, including heating, ventilation, domestic hot water and lighting (lighting operation time per year shorter than $2500 \mathrm{~h}$ ), set in Polish law [55] was 110 and $70 \mathrm{kWh} / \mathrm{m}^{2}$, since 1 January 2017 and 31 December 2020, respectively. Although in the case of a building undergoing reconstruction, the fulfillment of the EP condition is not required, it is worth comparing these data, in order to be aware of how much these non-modernized buildings differ in their energy standard from the current requirements. 


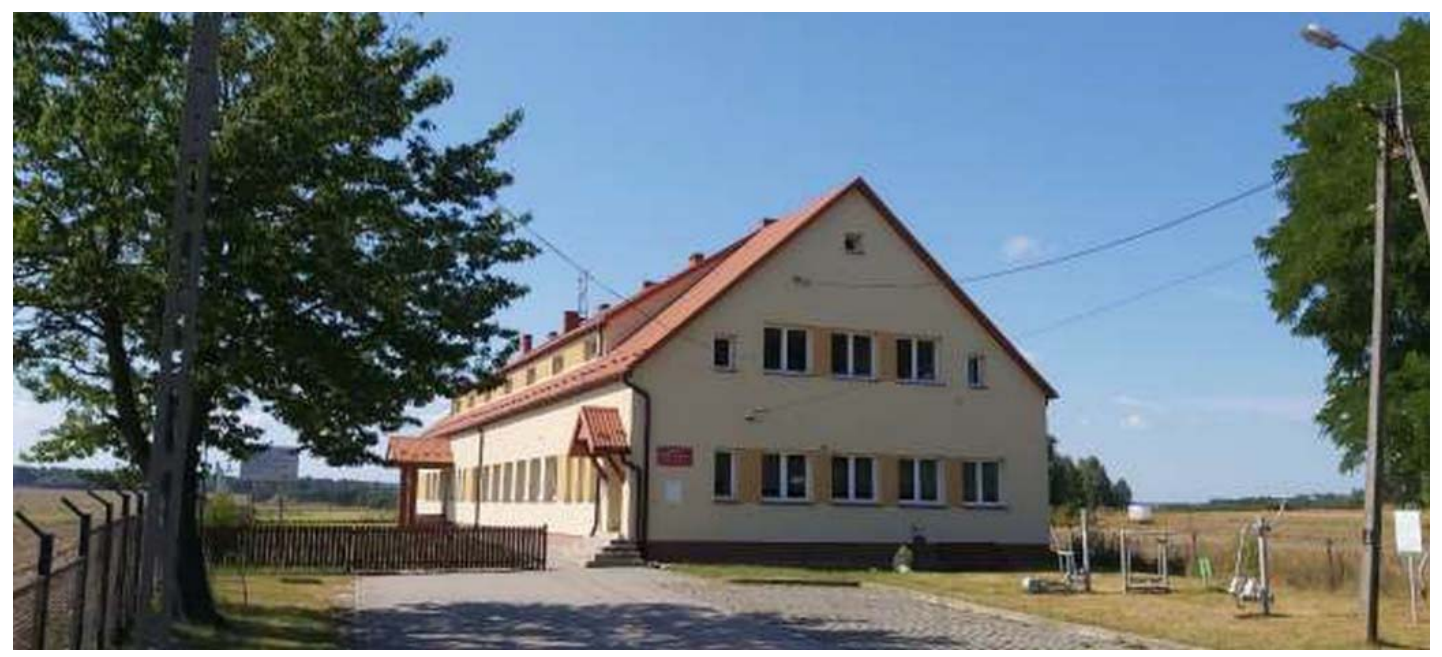

Figure 7. View of the school after modernization.

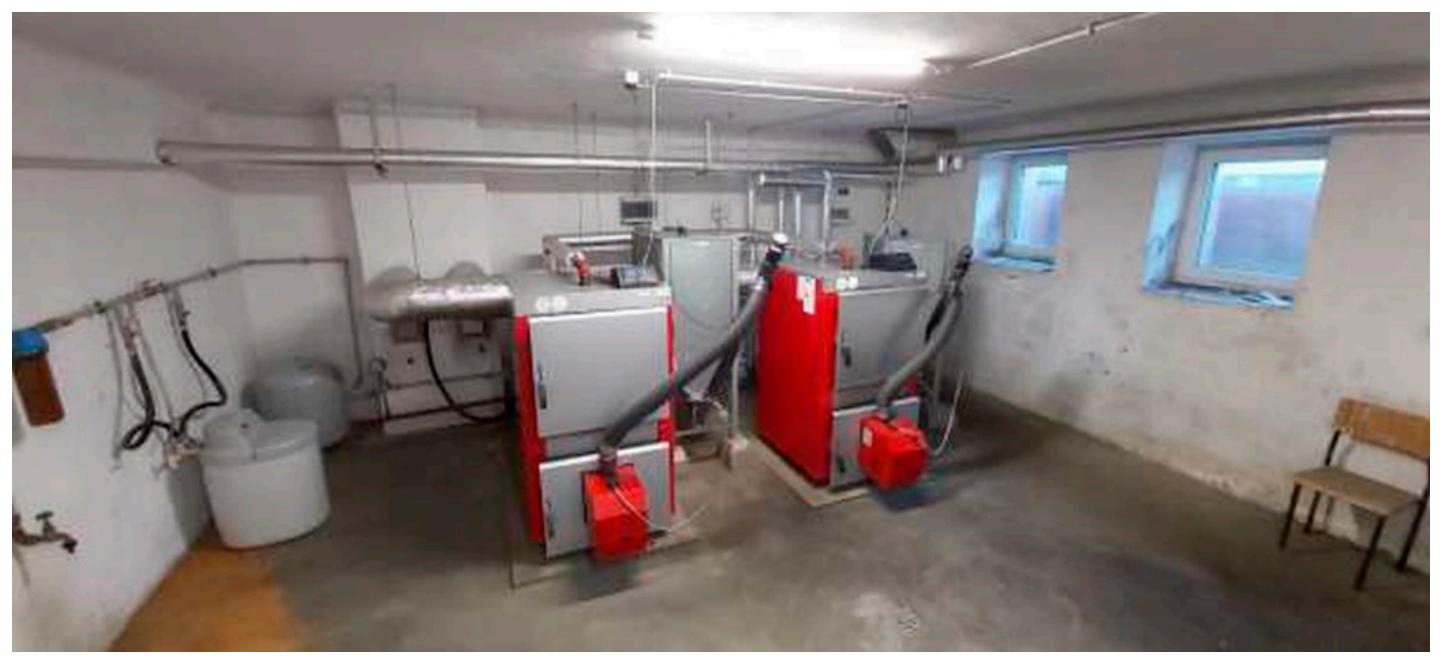

Figure 8. New boiler room.

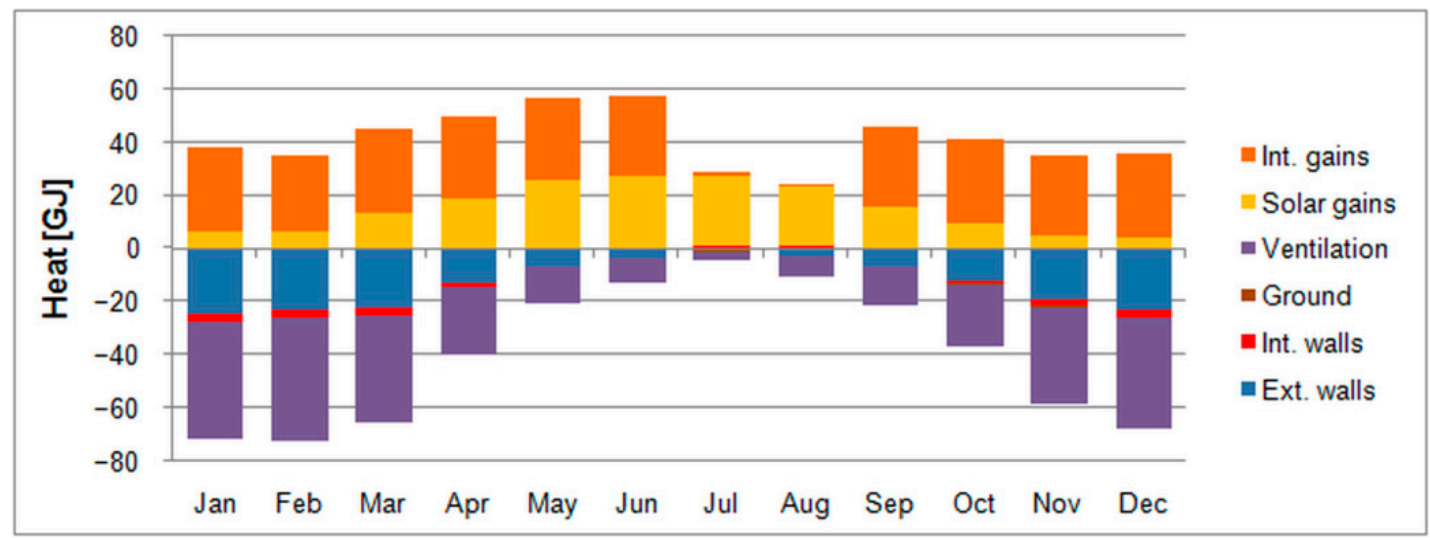

Figure 9. Heat gains and losses in the building after modernization. 
Table 5. Effectiveness of the modernization.

\begin{tabular}{cccc}
\hline Quantity & Before Modernization & After Modernization & Unit \\
\hline EP & 484.4 & 129.5 & $\mathrm{kWh} / \mathrm{m}^{2}$ \\
EK & 368.9 & 131.6 & $\mathrm{kWh} / \mathrm{m}^{2}$ \\
EU & 173.8 & 73.6 & $\mathrm{kWh} / \mathrm{m}^{2}$ \\
\hline
\end{tabular}

Several studies also presented results of energy performance investigations in European schools. In the study [82] on energy consumption in ten Greek schools, estimated total primary energy consumption (heating, hot water, and lighting) varied from 91.3 to $628.5 \mathrm{~kW} / \mathrm{m}^{2}$. According to Reference [83] primary heating energy in primary schools was from $119 \mathrm{kWh} / \mathrm{m}^{2}$ in the Netherlands, 164 in the UK, $165 \mathrm{kWh} / \mathrm{m}^{2}$ in Finland to $175 \mathrm{kWh} / \mathrm{m}^{2}$ in Denmark. In Reference [84] estimated heating energy consumption in three Finnish schools was from 116 to $157 \mathrm{kWh} / \mathrm{m}^{2}$ and from 115 to $140 \mathrm{kWh} / \mathrm{m}^{2}$ before and after their modernization, respectively. In a review for different European countries and kinds of schools [85], total energy consumption was from 52 to $197 \mathrm{kWh} / \mathrm{m}^{2}$.

Annual electricity consumption per usable floor area decreased in the analyzed school from 31.1 to $25.6 \mathrm{kWh} / \mathrm{m}^{2}$. In Reference [83], values of 28 to $51 \mathrm{kWh} / \mathrm{m}^{2}$ in Dutch and UK schools, respectively, were given. In Finnish conditions [84], they amounted from 57 to $72 \mathrm{kWh} / \mathrm{m}^{2}$ and from 57 to $63 \mathrm{kWh} / \mathrm{m}^{2}$ before and after an upgrade, respectively.

Alsabry [86] presented calculation results from energy audits of forty different buildings in Zielona Góra (West Poland). For four schools, the highest final energy use for heating was in buildings built before 1970 and amounted to about $400 \mathrm{kWh} / \mathrm{m}^{2}$. In the group built between 1970 and 1995, it amounted to about $230 \mathrm{kWh} / \mathrm{m}^{2}$. For objects built after 2008 , this parameter was $200 \mathrm{kWh} / \mathrm{m}^{2}$. The average efficiency of the central heating and DHW systems was from $51 \%$ and $56 \%$ to $78 \%$ and $50 \%$ before and after modernization. The total efficiency of the central heating and DHW installations in buildings built from 1970 to 1995 was from $73 \%$ and $55 \%$ to $78 \%$ and $55 \%$ before and after modernization, respectively. EK and EP indicators decreased from 394 and $549 \mathrm{kWh} / \mathrm{m}^{2}$ to 318 and $473 \mathrm{kWh} / \mathrm{m}^{2}$, accordingly. The average reduction of EU amounted to $24 \mathrm{kWh} / \mathrm{m}^{2}$.

Życzyńska et al. [37] discussed the effects of an 8-years monitoring campaign before and after thermal renovation of nine education buildings (two kindergartens and seven schools) built between 1961 and 1985 and located in Southeast Poland. Their heating demand was from 131.4 to $409.2 \mathrm{kWh} / \mathrm{m}^{2}$ and from 62.6 to $240.7 \mathrm{kWh} / \mathrm{m}^{2}$ before and after retrofit, respectively. The average heating energy saving was from $35 \%$ to $57 \%$.

\subsection{Environmental Effects}

To estimate the environmental effects of the given modernization investment air pollutants emissions are determined before and after its implementation [87]. Annual emission of pollutants, $\mathrm{E}_{0}$ and $\mathrm{E}_{1}$, before and after modernization, respectively, is given by the following relationship:

$$
\mathrm{E}_{0}, \mathrm{E}_{1}=\mathrm{B} \cdot \mathrm{EF}
$$

if the emission factor, EF, is given per unit of used fuel. B is an annual amount of used fuel. When EF is given per unit chemical energy in the fuel, that equation is modified:

$$
\mathrm{E}_{0}, \mathrm{E}_{1}=\mathrm{B} \cdot \mathrm{w} \cdot \mathrm{EF}
$$

where $\mathrm{w}$ is calorific value, published by the National Centre for Emissions Management (KOBiZE) [88] for typical fuels used in Poland. This institution also updates and publishes every year emission factors for electrical energy. They may change due to the modernization and development of the Polish power plants and power networks. For this reason, different values of EF for electricity were assumed in the considered audit for the state before and after modernization (Table 6). Values for hard coal were calculated following [89] taking into account the quality of coal used in the school. In the next step electricity, coal and 
wood consumption was calculated (Table 7) assuming $\mathrm{w}=20.7 \mathrm{MJ} / \mathrm{kg}$ and $9.69 \mathrm{GJ} / \mathrm{m}^{3}$ for coal and wood, respectively. From this, applying Equations (14) and (15) annual emissions of pollutants were derived (Table 8). A complete view of effects was obtained taking into account $5233 \mathrm{kWh}$ generated by the PV installation.

Table 6. Emission factors for hard coal, electricity, and wood [90-93].

\begin{tabular}{|c|c|c|c|c|c|c|c|}
\hline Energy Carrier & Unit & $\mathrm{SO}_{2}$ & $\mathrm{NO}_{2}$ & $\mathrm{CO}$ & $\mathrm{CO}_{2}$ & Dust & $\mathrm{BaP}$ \\
\hline Hard coal & $\mathrm{g} / \mathrm{GJ}$ & 424.7 & 24.16 & 1207.7 & 114010 & 435 & 0.048 \\
\hline Electricity ${ }^{1}$ & $\mathrm{~kg} / \mathrm{MWh}$ & 1.572 & 1.049 & 0.234 & 806.1 & 0.064 & 0 \\
\hline Wood & $\mathrm{g} / \mathrm{GJ}$ & 15 & 100 & 350 & 101100 & 50 & 0.015 \\
\hline Electricity $^{2}$ & $\mathrm{~kg} / \mathrm{MWh}$ & 0.681 & 0.631 & 0.275 & 765.0 & 0.036 & 0 \\
\hline
\end{tabular}

${ }^{1}$ For $2016 .^{2}$ For 2019.

Table 7. Annual consumption of energy carriers.

\begin{tabular}{ccc}
\hline Variant & Fuel & Consumption \\
\hline \multirow{2}{*}{ Before modernization } & Hard coal & $44.03 \mathrm{Mg}$ \\
& Electricity & $40,605.78 \mathrm{kWh}$ \\
After modernization & Wood pellets & $24.2 \mathrm{~m}^{3}$ \\
& Electricity & $40,443.22 \mathrm{kWh}$ \\
\hline
\end{tabular}

Table 8. Annual emission of pollutants, $\mathrm{kg}$ /year.

\begin{tabular}{ccccccc}
\hline Variant & $\mathbf{S O}_{\mathbf{2}}$ & $\mathrm{NO}_{\mathbf{2}}$ & $\mathbf{C O}$ & $\mathrm{CO}_{\mathbf{2}}$ & Dust & BaP \\
\hline Before modernization & 450.91 & 64.62 & 1110.22 & 136,643 & 399.07 & 0.04 \\
After modernization & 31.06 & 48.97 & 93.20 & 54,646 & 13.18 & 0.00 \\
After modernization, PV & 27.50 & 45.67 & 91.76 & 50,643 & 12.99 & 0.00 \\
\hline
\end{tabular}

PV, photovoltaic.

The most significant, over 30 times, was the reduction of dust emission. On the second position was sulfur dioxide emission reduced over 14 times. These values are better when considering the PV installation. A very important aspect of the use of fuel from wood waste is, in the case of the analyzed location, the use of locally available energy resources.

\subsection{Durability Analysis}

Over time, the physical properties of materials change due to the influence of several factors: atmospheric, operational and accidental events. For this reason, the durability of various materials has been tested for many years in terms of the loss of their operational properties, important for the user.

Several studies considering the exploitation durability of building materials and components of their technical systems have been published recently. In Reference [94], a review of windows constructions and their parameters was presented.

Based on the considered studies, authors estimated the lifespan of windows to be from 25 to 40 years. For PVC, aluminum and wood frames it ranged from 30 to 50 years, whereas for glazing it was about 20 years. Maia et al. [95] analyzed 173 aluminum and 41 wooden window frames. The estimated service life of aluminum and wooden frames was between 37 and 41 years and about 28 years, respectively. Gulck et al. [96] studied facades renovation strategies of apartment buildings in Flanders. The typical lifespan of EPS, stone wool, and PUR was over 60 years. The lifespan of buildings is estimated usually at 50-100 years [97-99]. The results presented in other studies are shown in Table 9. 
Table 9. The lifespan of typical construction materials and buildings equipment.

\begin{tabular}{|c|c|c|c|c|c|}
\hline Material/Construction & Reference [96] & Reference [100] & Reference [101] & Reference [102] & Reference [103] \\
\hline Concrete/brick & - & $80-120$ & 120 & - & - \\
\hline EPS insulation & $>60$ & - & - & 40 & 40 \\
\hline Glass wool insulation & $>60$ & $40-60$ & & 30 & 30 \\
\hline Doors & - & - & 20 & - & - \\
\hline Windows & - & - & 20 & 30 & 30 \\
\hline Natural gas boiler & - & - & - & 20 & 20 \\
\hline PV modules & - & - & - & 20 & 25 \\
\hline
\end{tabular}

The school was built in 1970. During modernization, it had 47 years. In such a case, it seems advisable to carry out additional examinations of the technical condition of the building partitions to be insulated before the construction works are carried out. Almost 50 years of exposure to weather conditions on the site cause aging of many elements. However, in the energy audit of the school, the problem of its technical condition was treated in a simplified manner. Based on the on-site inspection, it was only stated that "the general condition of the building's structural elements is bad". The faults noticed in more detail were not indicated. Therefore, it should be concluded that this opinion concerned the generation of heat losses, and their structural condition (operational safety) did not raise any doubts.

Because the school was built in traditional technology, from bricks on the concrete foundation, it may be assumed that its lifespan is about $100-120$ years. This gives about 50-70 years of perspective operation. A comparison of this value with SPBT shown in Table 4 may lead to the conclusion of the legitimacy of some modernization measures with the longest SPBT. In this case, the insulation of the wooden external wall has SPBT of 87 years, and it will not pay off over the lifetime of the building. On the other hand, it cost only $1.52 \%$ of the total cost, which had almost no impact on the whole project. If not implementing this part of the modernization, a full assumed energy effect would not be reached. This example shows that such situations arise in real cases and should be approached carefully, so as not to squander the possibility of modernization and, on the other hand, to avoid unnecessary public spending.

\section{Conclusions}

Implementation of the described project resulted in a noticeable reduction of energy demand for space heating from 464.78 to 168.73 GJ. Primary energy consumption (EP) decreased from 484.4 to $129.5 \mathrm{kWh} / \mathrm{m}^{2}$. Presented completed combination of thermal refurbishment with heating system modernization and installation of photovoltaic modules resulted also in significantly lower annual emissions of sulfur dioxide and dust: from 450.91 to $27.50 \mathrm{~kg}$ and from 399.07 to $12.99 \mathrm{~kg}$, respectively.

Moreover, attention was paid to economic issues. Required by Polish regulation, simple payback time was calculated for all, indicated in audit, modernization measures. It was from 15.8 years for additional insulation of the ceiling under the unheated attic, 16.1 years for insulation of the external brick wall to 70 years for modernization of the central heating installation, and 87 years for insulation of the wooden external wall.

The building was put into use in 1970. As the technical condition of the building's construction elements did not raise any objections, its useful life, as can be assumed in the literature, is 100-120 years. Considering that the payback time for the entire project was 35.6 years, it can be assumed that this is a fully acceptable value in terms of the durability of the facility. However, this issue requires a further and more detailed economic and technical analysis, taking into account the technical condition of the building, the predicted lifespan of the building, and planned investment or the possible variations in the economic environment, especially energy price. 
Author Contributions: Conceptualization, P.M. and K.S.; methodology, K.S.; software, K.S.; validation, P.M.; formal analysis, K.S. and J.S.; investigation, P.M.; resources, K.S.; data curation, K.S.; writing-original draft preparation, P.M.; writing-review and editing, P.M.; visualization, J.S.; supervision, P.M. All authors have read and agreed to the published version of the manuscript.

Funding: This research received no external funding.

Institutional Review Board Statement: Not applicable.

Informed Consent Statement: Not applicable.

Data Availability Statement: Not applicable.

Conflicts of Interest: The authors declare no conflict of interest.

\section{References and Notes}

1. Życzyńska, A.; Cholewa, T. The profitability analysis of enhancement of parameters of the thermal insulation of building partitions. Arch. Civ. Eng. 2014, LX, 335-347. [CrossRef]

2. Kozik, R.; Karasińska-Jaśkowiec, I. Green public procurement-Legal base and instruments supporting sustainable development in the construction industry in Poland. In E3S Web of Conferences; EDP Sciences: Les Ulis, France, 2016; p. 00044. [CrossRef]

3. Ramczyk, M. Legal bases and economic conditions of applying renewable energy resources in construction industry. In MATEC Web of Conferences; EDP Sciences: Les Ulis, France, 2018; Volume 174, p. 04004. [CrossRef]

4. Dołega, W. Selected aspects of national economy energy efficiency. Polityka Energetyczna 2019, 22, 19-32. [CrossRef]

5. Jezierski, W.; Sadowska, B.; Pawłowski, K. Impact of Changes in the Required Thermal Insulation of Building Envelope on Energy Demand, Heating Costs, Emissions, and Temperature in Buildings. Energies 2021, 14, 56. [CrossRef]

6. Firlag, S.; Piasecki, M. NZEB Renovation Definition in a Heating Dominated Climate: Case Study of Poland. Appl. Sci. 2018, 8, 1605. [CrossRef]

7. Wyrwa, A.; Figórski, A.; Guła, A. Policy instruments for supporting energy efficiency in Poland. Energy Environ. 2004, 15, 261-270. Available online: http:/ / www.jstor.org/stable/43735485 (accessed on 15 February 2021). [CrossRef]

8. Jędrzejuk, H.; Dybiński, O. The influence of a heating system control program and thermal mass of external walls on the internal comfort in the Polish climate. Energy Procedia 2015, 78, 1087-1092. [CrossRef]

9. Energy Efficiency in Poland in Years 2005-2015. Central Statistical Office, Warsaw. 2017. Available online: https://stat.gov.pl/en/ topics/environment-energy/energy/energy-efficiency-in-poland-in-years-2005-2015,5,13.html (accessed on 16 February 2021).

10. Michalak, P. The development and validation of the linear time varying Simulink-based model for the dynamic simulation of the thermal performance of buildings. Energy Build. 2017, 141, 333-340. [CrossRef]

11. Chodkowska-Miszczuk, J.; Szymańska, D. Modernisation of public buildings in Polish towns and the concept of sustainable building. Quaest. Geogr. 2014, 33, 89-99. [CrossRef]

12. Sadowska, B. Effects of deep thermal modernization and use of renewable energy in public buildings in north-eastern Poland. In Proceedings of the 20th International Scientific Conference Engineering for Rural Development, Jelgava, Latvia, 26-28 May 2018; Malinovska, L., Osadcuks, V., Eds.; Latvia University of Life Sciences and Technologies: Jelgava, Latvia, 2018; pp. 1870-1875. [CrossRef]

13. Nowak-Dzieszko, K.; Rojewska-Warchał, M. Thermal comfort of the individual flats of multi-family panel building. Tech. Trans. Civil. Eng. 2014, 5-B/2014, 201-206. [CrossRef]

14. Orzechowski, T.; Orzechowski, M. Energy savings due to building insulation of different thickness. In E3S Web of Conferences; EDP Sciences: Les Ulis, France, 2017; Volume 14, p. 01030. [CrossRef]

15. Blaszczok, M.; Baranowski, A. Thermal improvement in residential buildings in view of the indoor air quality-Case study for Polish dwelling. Arch. Civ. Eng. Environ. 2018, 11, 121-130. [CrossRef]

16. Gładyszewska-Fiedoruk, K.; Krawczyk, D.A. The possibilities of energy consumption reduction and a maintenance of indoor air quality in doctor's offices located in north-eastern Poland. Energy Build. 2014, 85, 235-245. [CrossRef]

17. Energy Efficiency in Poland in Years 1997-2007, Central Statistical Office, Warsaw. 2009. Available online: https://stat.gov.pl/ cps/rde/xbcr/gus/ee_energy_efficiency_in_Poland_1997-2007.pdf (accessed on 21 February 2021).

18. Szul, T. The consumption of final energy for heating educational facilities located in rural areas. J. Res. Appl. Agric. Eng. 2017, 62, 71-175. Available online: https://www.pimr.eu/wp-content/uploads/2019/05/2017_1_TS.pdf (accessed on 16 February 2021).

19. Lis, P. Estimated potential for energy savings in heating residential buildings in Poland. E3S Web of Conferences; EDP Sciences: Les Ulis, France, 2018; Volume 49, p. 00068. [CrossRef]

20. The potential for Investment in Energy Efficiency through Financial Instruments in the European Union-Poland in-Depth Analysis. European Commission 2020, Brussels. Available online: https://www.fi-compass.eu/erdf/potential-investmentenergy-efficiency-through-financial-instruments-european-union/poland (accessed on 20 March 2021).

21. Gołabeska, E. The impact of the energy efficiency of the building to its market value. Econ. Environ. 2019, 70, 55-62. [CrossRef] 
22. Krawczyk, D.A. (Ed.) Buildings 2020+. Constructions, Materials and Installations; Printing House of Bialystok, Univesity of Technology: Bialystok, Poland; Cordoba, Spain; Vilnius, Lithuania, 2019. [CrossRef]

23. Księżopolski, K.; Drygas, M.; Pronińska, K.; Nurzyńska, I. The Economic Effects of New Patterns of Energy Efficiency and Heat Sources in Rural Single-Family Houses in Poland. Energies 2020, 13, 6358. [CrossRef]

24. Hybka, M.M.; Kaczyńska, A. Financing Primary Education in Poland-Challenges and controversies. In Proceedings of the 2nd International Conference on Institutional Leadership, Learning \& Teaching (ILLT), Cambridge, UK, 20-21 September 2016; Available online: https://cberuk.com/cdn/conference_proceedings/2019-07-20-11-55-01-AM.pdf (accessed on 20 March 2021).

25. Wojniak, J.; Majorek, M. Polish education system under 2017 reform: Assumptions, aims and controversies. In SHS Web of Conferences; EDP Sciences: Les Ulis, France, 2018; Volume 48, p. 01043. [CrossRef]

26. Firlag, S.; Staniaszek, D. Financing Building Energy Performance Improvement in Poland; Project: Energy Efficiency in EU Buildings; Buildings Performance Institute Europe (BPIE): Brussels, Belgium, 2016. [CrossRef]

27. Bernardo, H.; Gaspar, A.; Henggeler Antunes, C. A Combined Value Focused Thinking-Soft Systems Methodology Approach to Structure Decision Support for Energy Performance Assessment of School Buildings. Sustainability 2018, 10, 2295. [CrossRef]

28. Aminu Umar, U.; Khamidi, M.F.; Shika, S.A.; Musa, U. Towards Building Energy Efficiency for Developing Countries. Bonfring Int. J. Ind. Eng. Manag. Sci. 2013, 3, 13-19. [CrossRef]

29. Krawczyk, D.A. Retrofitting of a Heritage Building-Technical and Legal Constraints, Possible to Achieve Economic Effect. Int J. Struct. Civ. Eng. Res. 2019, 8, 277-279. [CrossRef]

30. Skiba, M.; Rzeszowska, N. Analysis of the dependence between energy demand indicators in buildings based on variants for improving energy efficiency in a school building. Civ. Environ. Eng. Rep. 2017, 26, 031-041. [CrossRef]

31. Gradziuk, P.; Gradziuk, B. Economic efficiency of applying a heat pump system in heating based on the example of the Ruda-Huta commune experience. Annals PAAAE 2019, XXI, 88-96. [CrossRef]

32. Zimny, J.; Michalak, P. The work of a heating system with renewable energy sources (RES) in school building. Environ. Prot. Eng. 2008, 34, 81-88. Available online: http:/ / epe.pwr.wroc.pl/2008/Zimny_1-2008.pdf (accessed on 15 February 2021).

33. Zimny, J.; Michalak, P.; Szczotka, K. The energy efficiency of a school building hybrid heating system with a heat pump. A case study. Rynek Energii 2012, 2012, 144-152. Available online: http:/ / pga.org.pl/biblioteka/artykuly/The_energy_efficiency_of_a_ school_building_hybrid_heating_system.pdf (accessed on 15 February 2021).

34. Krawczyk, D.A. Theoretical and real effect of the school's thermal modernization-A case study. Energy Build. 2014, 81, 30-37. [CrossRef]

35. Lis, A.; Ujma, A. Evaluation of thermal modernization of school building in terms of energy saving. Fizyka Budowli w TeoriiiPraktyce 2016, VIII, 15-20. Available online: http:/ /yadda.icm.edu.pl/yadda/element/bwmeta1.element.baztech-03d9ce55-494f-4f04-91 e2-bae0cda90905 (accessed on 15 February 2021).

36. Tucki, K.; Sikora, M. Modernisation of a Coal-Fired Heating Plant to Switch to Woodchips, in Accordance with Logistics Principles. TEKA Comm. Mot. Energetics Agric. 2016, 16, 65-70. Available online: http://journals.pan.pl/dlibra/publication/124173/edition/ 108348 / content (accessed on 15 February 2021).

37. Życzyńska, A.; Suchorab, Z.; Kočí, J.; Černý, R. Energy Effects of Retrofitting the Educational Facilities Located in South-Eastern Poland. Energies 2020, 13, 2449. [CrossRef]

38. Dec, K.; Broniewicz, E.; Broniewicz, M. The Possibility Analysis of Adapting a Public Building to the Standard of a Building with a Zero Energy Balance. Energies 2020, 13, 6389. [CrossRef]

39. Basińska, M.; Koczyk, H.; Kosmowski, A. Assessment of thermo modernization using the global cost method. Energy Procedia 2015, 78, 2040-2045. [CrossRef]

40. Basińska, M.; Kaczorek, D.; Koczyk, H. Building Thermo-Modernisation Solution Based on the Multi-Objective Optimisation Method. Energies 2020, 13, 1433. [CrossRef]

41. Congedo, P.M.; D’Agostino, D.; Baglivo, C.; Tornese, G.; Zacà, I. Efficient Solutions and Cost-Optimal Analysis for Existing School Buildings. Energies 2016, 9, 851. [CrossRef]

42. Dylewski, R. Optimal Thermal Insulation Thicknesses of External Walls Based on Economic and Ecological Heating Cost. Energies 2019, 12, 3415. [CrossRef]

43. Dylewski, R.; Adamczyk, J. Impact of the Degree Days of the Heating Period on Economically and Ecologically Optimal Thermal Insulation Thickness. Energies 2021, 14, 97. [CrossRef]

44. Oregi, X.; Hernández, R.J.; Hernandez, P. Environmental and Economic Prioritization of Building Energy Refurbishment Strategies with Life-Cycle Approach. Sustainability 2020, 12, 3914. [CrossRef]

45. Dobrzycki, A.; Kurz, D.; Mikulski, S.; Wodnicki, G. Analysis of the Impact of Building Integrated Photovoltaics (BIPV) on Reducing the Demand for Electricity and Heat in Buildings Located in Poland. Energies 2020, 13, 2549. [CrossRef]

46. Zheng, L.; Lai, J. Environmental and economic evaluations of building energy retrofits: Case study of a commercial building. Build. Environ. 2018, 145, 14-23. [CrossRef]

47. Yan, Y.; Zhang, H.; Meng, J.; Long, Y.; Zhou, X.; Li, Z.; Wang, Y.; Liang, Y. Carbon footprint in building distributed energy system: An optimization-based feasibility analysis for potential emission reduction. J. Clean. Prod. 2019, 239, 117990. [CrossRef] 
48. Fenner, A.E.; Kibert, C.J.; Li, J.; Razkenari, M.A.; Hakim, H.; Lu, X.; Kouhirostami, M.; Sam, M. Embodied, operation, and commuting emissions: A case study comparing the carbon hotspots of an educational building. J. Clean. Prod. 2020, $268,122081$. [CrossRef]

49. Yongtao, L.; Chao, H.; Xiuqin, M.; Fankun, W. Co-benefit Research on Energy Efficiency Reforming Project of District Heating System. Energy Procedia 2011, 5, 598-603. [CrossRef]

50. Proszak-Miąsik, D.; Rabczak, S. Methods for reducing low emissions from heating devices in single-family housing. In E3S Web of Conferences; EDP Sciences: Les Ulis, France, 2018; Volume 45, p. 00069. [CrossRef]

51. Kaczmarczyk, M.; Sowiżdżał, A.; Tomaszewska, B. Energetic and Environmental Aspects of Individual Heat Generation for Sustainable Development at a Local Scale-A Case Study from Poland. Energies 2020, 13, 454. [CrossRef]

52. Raczyński, M.; Rutkowski, R. How Pro-Environmental Legal Regulations Affect the Design Process and Management of Multi-Family Residential Buildings in Poland. Energies 2020, 13, 5449. [CrossRef]

53. Act of November 21, 2008 on supporting thermo-modernization and renovation. J. Laws 2008, No. 223, item 1459.

54. Regulation of the Minister of Infrastructure of 17 March 2009 on the Detailed Scope and Form of the Energy Audit and Part of the Renovation Audit, Audit Card Templates, as well as algorithms for assessing the profitability of a thermo-modernization project. J. Laws 2009, No. 43, item 346.

55. Regulation of the Minister of Infrastructure and Development of 27 February 2015 on the methodology for determining the energy performance of a building or part of a building and energy performance certificates. J. Laws 2015, No. 376.

56. Ordinance of the Minister of Infrastructure of 12 April 2002 (as amended) on technical conditions to be met by buildings and their location. J. Laws 2002, No. 75, item 690, as amended.

57. Regulation of the Minister of Economy of 10 August 2012 on the detailed scope and method of preparing an energy efficiency audit, template of an energy efficiency audit card and methods of calculating energy savings. J. Laws 2012, item 962.

58. Borys, G. Selected directions of increasing efficiency in supporting thermomodernization in buildings from public funding. Res. Pap. Wrocław Univ. Econ. 2015, 397, 68-77. [CrossRef]

59. Mędrzycki, R.; Szyrski, M. Energy Poverty as a European Union and Polish Legal Issue. Białostockie Studia Prawnicze 2018, 23, 125-138. [CrossRef]

60. Petryk, A.; Guzdek, S. The influence of thermo-modernization on the low-stack emission reduction-A case study of a singlefamily house. Infrastruct. Ecol. Rural Areas 2018, 1045-1056. [CrossRef]

61. Życzyńska, A.; Cholewa, T. The modifications to the requirements on energy savings and thermal insulation of buildings in Poland in the years 1974-2021. Budownictwoi Architektura 2015, 14, 145-154. Available online: https://ph.pollub.pl/index.php/ $\mathrm{bia} /$ article/view /1680 (accessed on 16 February 2021). [CrossRef]

62. Redlarski, G.; Wojdalski, J.; Kupczyk, A.; Piechocki, J. Efficiency of biomass energy used for heating purposes in a residential building in comparison with other energy sources. TEKA Comm. Mot. Energ. Agric. 2012, 12, 211-218.

63. Basińska, M.; Koczyk, H. Analysis of the possibilities to achieve the low energy residential buildings standards. Technol. Econ. Dev. Econ. 2016, 22, 830-849. [CrossRef]

64. Krawczyk, D.A. Analysis of Energy Consumption for Heating in a Residential House in Poland. Energy Procedia 2016, 95, $216-222$. [CrossRef]

65. Piotrowska, E.; Borchert, A. Energy consumption of buildings depends on the daylight. In E3S Web of Conferences; EDP Sciences: Les Ulis, France, 2017; Volume 14, p. 01029. [CrossRef]

66. Bekierski, D.; Geryło, R.; Kaczorek, D.; Perczyński, P. EPBD Implementation in Poland, Status in December 2016, Concerted Action EPBD. 2018. Available online: https://www.buildup.eu/sites/default/files/content/ca-epbd-iv-poland-2018.pdf (accessed on 15 February 2021).

67. Sobczyk, W.; Sapa, K. Energy balance in a passive solar building. An attempt at economic assessment. In E3S Web of Conferences; EDP Sciences: Les Ulis, France, 2016; Volume 10. [CrossRef]

68. Sikora, M.; Siwek, K. Energy audit of the residential building. J. Mech. Energy Eng. 2018, 2, 317-328. [CrossRef]

69. Hałacz, J.; Skotnicka-Siepsiak, A.; Neugebauer, M. Assessment of Reducing Pollutant Emissions in Selected Heating and Ventilation Systems in Single-Family Houses. Energies 2020, 13, 1224. [CrossRef]

70. PN EN 12831-1: 2017. Energy Performance of Buildings-Method for Calculation of the Design Heat Load; Polish Committee of Standardisation: Warsaw, Poland, 2017.

71. Typical Meteorological Years. The Ministry of Infrastructure and Development. Available online: https://archiwum.miir.gov.pl/ strony/zadania/budownictwo/charakterystyka-energetyczna-budynkow / dane-do-obliczen-energetycznych-budynkow-1/ (accessed on 16 February 2021).

72. Nowak, S. Management of Heat Energy Consumption In Poland For The Purpose Of Buildings' Heating And Preparation Of Useable, Hot Water. Annales Universitatis Apulensis Series Oeconomica 2009, 11, 895-901. Available online: http://www. oeconomica.uab.ro/upload/lucrari/1120092/33.pdf (accessed on 15 February 2021).

73. Dylewski, R.; Adamczyk, J. The environmental impacts of thermal insulation of buildings including the categories of damage: A Polish case study. J. Clean. Prod. 2016, 137, 878-887. [CrossRef]

74. Firlag, S. Cost-Optimal Plus Energy Building in a Cold Climate. Energies 2019, 12, 3841. [CrossRef]

75. Krzeszowski, Ś. Evaluation of the usefulness of selected computer programs in the context of educating students of the environmental engineering. Chem. Didact. Ecol. Metrol. 2015, 20, 31-37. [CrossRef] 
76. Mindykowski, D. Optimization of Heating and Cooling System for a Passive House Equipped with Heat Pump and Heat Storage. Master's Thesis, Norwegian University of Science and Technology, Trondheim, Norway, 2016. Available online: https://ntnuopen.ntnu.no/ntnu-xmlui/handle/11250/2405175 (accessed on 15 February 2021).

77. PN-EN ISO 13790:2009. Energy Performance of Buildings. In Calculation of Energy Use for Space Heating and Cooling; The Polish Committee for Standardization: Warszawa, Poland, 2009.

78. Ferrari, S.; Romeo, C. Retrofitting under protection constraints according to the nearly Zero Energy Building (nZEB) target: The case of an Italian cultural heritage's school building. Energy Procedia 2017, 140, 495-505. [CrossRef]

79. Berardi, U.; Manca, M.; Casaldaliga, P.; Pich-Anguilera, F. From high Energy demand to nZEB: The retrofit of a school in Catalonia, Spain. Energy Procedia 2017, 140, 141-150. [CrossRef]

80. Brandão de Vasconcelos, A.; Pinheiro, M.D.; Manso, A.; Cabaço, A. EPBD cost-optimal methodology: Application to the thermal rehabilitation of the building envelope of a Portuguese residential reference building. Energy Build. 2016, 111, 12-25. [CrossRef]

81. Fedorczak-Cisak, M.; Furtak, M.; Hayduk, G.; Kwasnowski, P. Energy Analysis And Cost Efficiency of External Partitions In Low Energy Buildings. IOP Conf. Ser. Mater. Sci. Eng. 2019, 471, 112095. [CrossRef]

82. Katsaprakakis, D.A.; Zidianakis, G. Upgrading Energy Efficiency for School Buildings in Greece. Procedia Environ. Sci. 2017, 38, 248-255. [CrossRef]

83. Dias Pereira, L.; Raimondo, D.; Corgnati, S.P.; Gameiro da Silva, M. Energy consumption in schools-A review paper. Renew. Sustain. Energy Rev. 2014, 40, 911-922. [CrossRef]

84. Sekki, T.; Airaksinen, M.; Saari, A. Effect of energy measures on the values of energy efficiency indicators in Finnish daycare and school buildings. Energy Build. 2017, 139, 124-132. [CrossRef]

85. Marrone, P.; Gori, P.; Asdrubali, F.; Evangelisti, L.; Calcagnini, L.; Grazieschi, G. Energy Benchmarking in Educational Buildings through Cluster Analysis of Energy Retrofitting. Energies 2018, 11, 649. [CrossRef]

86. Alsabry, A. Possibilities of decreasing energy consumption through thermal upgrading in selected buildings in Poland case study: The town of Zielona Góra. Energy Build. 2016, 130, 811-820. [CrossRef]

87. Woroniak, G.; Piotrowska-Woroniak, J. Effects of pollution reduction and energy consumption reduction in small churches in Drohiczyn community. Energy Build. 2014, 72, 51-61. [CrossRef]

88. Calorific Values (CO) and CO2 Emission Factors (EC) in 2013 for Reporting under the Community Emission Trading Scheme for 2016, National Centre for Emissions Management (KOBiZE), Warsaw. 2015. Available online: https: //www.kobize.pl/uploads/materialy/materialy_do_pobrania/monitorowanie_raportowanie_weryfikacja_emisji_w_eu_ets/ WO_i_WE_do_stosowania_w_SHE_2016.pdf (accessed on 20 March 2021).

89. Pollutant Emission Factors from Fuel Combustion in Boilers with a Rated Thermal Power Up to 5 MW [In Polish]. National Centre for Emissions Management (KOBiZE), Warsaw. 2015. Available online: https://krajowabaza.kobize.pl/docs/male_kotly.pdf (accessed on 20 March 2021).

90. $\mathrm{CO}_{2}, \mathrm{SO}_{2}, \mathrm{NO}_{\mathbf{X}}, \mathrm{CO}$ and Total Dust Emission Factors for Electricity [In Polish]. National Centre for Emissions Management (KOBiZE), Warsaw. 2015. Available online: https://www.kobize.pl/uploads/materialy/materialy_do_pobrania/wskazniki_ emisyjnosci/160616_WSKAZNIKI_zanieczyszczenia.pdf (accessed on 20 March 2021).

91. $\mathrm{CO}_{2}$ Emission Factors for Electricity at End Users [In Polish]. National Centre for Emissions Management (KOBiZE), Warsaw. 2015. Available online: https://www.kobize.pl/uploads/materialy/materialy_do_pobrania/wskazniki_emisyjnosci/160616 _WSKAZNIKI_CO2.pdf (accessed on 20 March 2021).

92. $\mathrm{CO}_{2}, \mathrm{SO}_{2}, \mathrm{NO}_{\mathrm{x}}, \mathrm{CO}$ and Total Dust Emission Factors for electricity [In Polish]. National Centre for Emissions Management (KOBiZE), Warsaw. 2019. Available online: https://www.kobize.pl/uploads/materialy/materialy_do_pobrania/wskazniki_ emisyjnosci/Wskazniki_emisyjnosci_grudzien_2019.pdf (accessed on 20 March 2021).

93. Factors of Pollutant Emissions from Fuel Combustion for Sources with a Nominal Thermal Power of up to 5 MW, Used for the Automatic Calculation of Emissions in the Report to the National Base for 2020 [In Polish]. National Centre for Emissions Management (KOBiZE), Warsaw. 2021. Available online: https:/ / krajowabaza.kobize.pl/docs/MATERIAL_wskazniki_male_ kotly_2020.pdf (accessed on 20 March 2021).

94. Souviron, J.; van Moeseke, G.; Khan, A.Z. Analysing the environmental impact of windows: A review. Build. Environ. 2019, 161, 106268. [CrossRef]

95. Maia, M.; Morais, R.; Silva, A. Application of the factor method to the service life prediction of window frames. Eng. Failure Anal. 2020, 109, 104245. [CrossRef]

96. Van Gulck, L.; Van de Putte, S.; Delghust, M.; Van Den Bossche, N.; Steeman, M. Environmental and financial assessment of façade renovations designed for change: Developing optimal scenarios for apartment buildings in Flanders. Build. Environ. 2020, 183, 107178. [CrossRef]

97. Goggins, J.; Moran, P.; Armstrong, A.; Hajdukiewicz, M. Lifecycle environmental and economic performance of nearly zeroenergy buildings (NZEB) in Ireland. Energy Build. 2016, 116, 622-637. [CrossRef]

98. Maslesa, E.; Jensen, P.A.; Birkved, M. Indicators for quantifying environmental building performance: A systematic literature review. J. Build. Eng. 2018, 19, 552-560. [CrossRef]

99. Sartori, T.; Calmon, J.L. Analysis of the impacts of retrofit actions on the life cycle energy consumption of typical neighbourhood dwellings. J. Build. Eng. 2019, 21, 158-172. [CrossRef] 
100. Mequignon, M.; AitHaddou, H.; Thellier, F.; Bonhomme, M. Greenhouse gases and building lifetimes. Build. Environ. 2013, 68, 77-86. [CrossRef]

101. Iddon, C.R.; Firth, S.K. Embodied and operational energy for new-build housing: A case study of construction methods in the UK. Energy Build. 2013, 67, 479-488. [CrossRef]

102. Ortiz, J.; Fonseca i Casas, A.; Saloma, J.; Garrido Soriano, N.; Fonseca i Casas, P. Cost-effective analysis for selecting energy efficiency measures forrefurbishment of residential buildings in Catalonia. Energy Build. 2016, 128, 442-457. [CrossRef]

103. Martínez Garriga, S.; Dabbagh, M.; Krarti, M. Optimal carbon-neutral retrofit of residential communities in Barcelona, Spain. Energy Build. 2020, 208, 109651. [CrossRef] 